Polemic

\title{
Why Social Movements Need Philosophy (A Reply to "Feminism without Philosophy: A Polemic" by Jeremiah Joven Joaquin)
}

Noelle Leslie G. dela Cruz

\begin{abstract}
This essay attempts to respond to two main claims presented in the article "Feminism without Philosophy: A Polemic" by Jeremiah Joven Joaquin (Kritike, 10:2, 2016). For Joaquin, (1) feminism, as a sociopolitical movement, does not need philosophy to explain the nature of gender inequality and that (2) feminism cannot achieve its main goals or concerns through philosophizing. I respond to these by questioning Joaquin's intended target, i.e., so-called "academic feminism"; countering his implicit assumption of a divide between theory and practice; and citing examples of recent feminist scholarly productions which use theory in the service of political advocacy. I conclude that his views are pernicious and therefore need to be corrected.
\end{abstract}

Keywords: feminism, feminist movement, academic feminism, theory and practice

$\mathrm{I}$ would like to respond to the claims made by Joaquin in his article "Feminism without Philosophy: A Polemic." ${ }^{1}$ As a whole, I find his essay 1 to be generally uninformed, not only about the nature of feminist discourse, but also about recent developments in it. A number of his assumptions are also clearly questionable.

First, I will restate his claims as best as I can, then present my arguments against them. Joaquin identifies two main problems in his paper: (1) "Does feminism, as a socio-political movement, need to have a philosophy concerning the nature of gender inequality?" and (2) "Would feminism achieve its main socio-political concerns by giving philosophical foundations

${ }^{1}$ Jeremiah Joven Joaquin, "Feminism without Philosophy: A Polemic," in Kritike, 10:2 (2016): 286-300.

(c) 2017 Noelle Leslie G. dela Cruz

http://www.kritike.org/journal/issue 20/dela cruz june2017.pdf

ISSN 1908-7330 


\section{A REPLY TO JOAQUIN}

for them?" 2 He answers "no" to both of these questions, treating the first as the simpler issue while offering a longer justification for his views in regard to the second. He believes that a certain kind of feminism in the academe, inasmuch as it is characterized by "fantastic theorizing," is ultimately "detrimental" to the main goal of the feminist movement, which is to combat the oppression of women by various social institutions. Too much theorizing supposedly leads to such adverse consequences as the trivialization of gender-related issues, the de-radicalization of the movement itself, and elitism among the ranks of feminists. Thus, feminists ought to stop trying to provide a theoretical explanation for gender oppression. By analogy, he argues, one doesn't need an aesthetic theory to justify the pragmatic policy of prohibiting the improper disposal of chewing gum waste. ${ }^{3}$ Instead of engaging in philosophy, feminists should bring their advocacies to the "proper forums," namely, the congress or the courts, in which some form of social change can be effected. ${ }^{4}$

It should be noted that Joaquin seems to consider the feminist critique of gender in the history of philosophy as a positive contribution to thought. He believes it is laudable because "it helps in the facilitation of libertarian ideas." ${ }^{5}$ However, what he does take issue with is the transformation of academic feminism into a "rigid doctrine," i.e., its becoming an ideology, with all the negative baggage that the word is saddled with, e.g., dogmatism and irrationality. He claims that feminism, originally a political movement for social change, had morphed into an ideology due to the development of academic feminism. ${ }^{6}$ His recommendation, therefore, is for feminists to abandon the academe and to focus their energies instead in "the public sphere." Exhorting feminists to "[g]o back to the streets and make their hands dirty," he claims that this is the only way they could accomplish their political objectives; in the meantime, "philosophical systems need not be built." 7

I wish to respond to the above claims by (1) questioning Joaquin's characterization of his intended target, i.e., the sort of "academic feminism" that theorizes too much; (2) countering his implicit assumption that there is, or should be, a clear dichotomy between theory and practice, between "the academe" (said to be the site of "ideology") and "the public sphere" (said to be the arena of social policy advocacy); and (3) citing recent feminist scholarly productions, whose existence contravenes the notion that philosophical theories or explanations are detrimental to the political goals of feminism.

\footnotetext{
2 Ibid., 287.

${ }^{3}$ Ibid., 288.

${ }^{4}$ Ibid., 298.

${ }^{5}$ Ibid., 293.

${ }^{6}$ Ibid., 295.

${ }^{7}$ Ibid., 299.
}

(c) 2017 Noelle Leslie G. dela Cruz

http://www.kritike.org/journal/issue 20/dela cruz june2017.pdf

ISSN 1908-7330

(c) BY-NC-ND 


\section{On "Academic Feminism"}

In his discussion of "academic feminism," Joaquin mentions at least three species of examples:

From the fashionable corridors of the academia, we might see a feminist philosopher in her academic gown discussing in highfaluting jargons why the word "womyn" is a better label than "women." Perhaps, we might also see them (the academic feminists) discussing the ontological status of social constructs such as sex, gender, and gender roles. Or perhaps, we might see the elaborate demonstrations by a well-known French feminist explaining her views on the inadequacy of the bipolarity of the epistemological concatenations that grilled the hybrid array of Otherness in the whole warmth of being. ${ }^{8}$

Notwithstanding the tongue-in-cheek spirit in which they have apparently been written, I believe that the above examples tend to grossly misrepresent feminism. Consequently, these unfounded opinions cannot support Joaquin's recommendations about what in fact feminists ought to do.

First, gender-neutral linguistic neologisms have not been predominantly adopted by feminists, and a term such as "womyn" has not gone uncontested in queer studies. In any case, whatever may be said about these neologisms, Joaquin's parody trivializes the significance of the insight from linguistics that language and thought are interrelated and that therefore, the terminologies or labels we use have the potential to reinforce oppressive attitudes.

Second, theories about sex and gender are integral to feminism, not only in the academic sense but also in the historical sense. The so-called "waves" of the feminist movement, i.e., the paradigm shift from women's rights (which can be traced back to the Enlightenment era) to women's liberation (which saw its heyday in the 1960s and '70s), is due in large part to the conceptual achievement of philosophical works such as The Second Sex by Simone de Beauvoir, first translated from French into English in 1953. Using existential-phenomenological tools, Beauvoir demonstrated that the oppression of women is not rooted in biology (sex), but in social and cultural practices (gender). In the seven decades since its inception, Beauvoir's insight has been explored, developed, and critiqued, paving the way for allied fields

${ }^{8}$ Ibid., 294.

(c) 2017 Noelle Leslie G. dela Cruz http://www.kritike.org/journal/issue 20/dela cruz june2017.pdf ISSN 1908-7330 


\section{A REPLY TO JOAQUIN}

such as gay and lesbian studies, men's studies, and queer studies. Indeed, when it comes to liberation struggles, theory and practice are intricately intertwined. (I shall return to this point in the next section.)

Third, Joaquin's reference to "a well-known French feminist" obscures the vast differences in style, framework, and method among French feminists, a group that can encompass anyone from Beauvoir to the poststructuralist feminists, or French difference feminists. To count as effective or rationally persuasive, any objection to their ideas should at the very least present a working understanding of their philosophical arguments. Clearly, no such understanding has been demonstrated. Therefore, feminism(s) have been misrepresented in Joaquin's article.

\section{On the Dichotomy between Theory and Practice}

The article also assumes, but does not sufficiently justify, a clear demarcation between theory and practice. This is the bedrock of Joaquin's call for feminists to leave the academe and to focus their energies in "the public sphere." ${ }^{9}$ I shall offer a more generous reading of this claim, rather than taking it to imply that educational institutions are not part of the socalled public sphere; such a view would only be true if all students were home-schooled. ${ }^{10}$ Instead, I shall take Joaquin's claim to mean that participation in certain arenas, such as the academe, tends to "de-radicalize" primarily social movements, such as feminism.

His premises in support of this conclusion rest on a certain characterization of "academic feminism," which I have already shown to be a misrepresentation. Therefore, in the absence of a more substantial argument from Joaquin himself, I shall discuss the key points presented in his source text, from which he borrows the phrase "academic feminism." I believe that Joaquin misreads this article, which is evincing a stand contrary to his own.

In their article entitled "Academic Feminism and the Process of DeRadicalization: Re-Examining the Issues,"11 Currie and Kazi refer to "academic feminism" as a type of institutionalized intellectualism, one that is separated from feminism as a social movement and is thereby "deradicalized," i.e., supporting, rather than challenging, the status quo. They cite Janet Radcliffe Richards, English author The Sceptical Feminist: A Philosophical Enquiry (1980), in which she makes a distinction between

${ }^{9}$ Ibid., 297.

${ }^{10}$ I use "public sphere" here in the ordinary sense. However, it should be noted that a classic feminist strategy has been to question the arbitrary separation of spheres, such as private/public and personal/political.

11 Dawn Currie and Hamida Kazi, "Academic Feminism and the Process of DeRadicalization: Re-Examining the Issues," in Feminist Review, 25 (1987): 77-98.

(C) 2017 Noelle Leslie G. dela Cruz

http://www.kritike.org/journal/issue 20/dela cruz june2017.pdf

ISSN 1908-7330

$((c))$ BY-NC-ND 
feminism as a rigid doctrine on the one hand, and feminism as a belief about sexual inequality, on the other hand. Currie and Kazi concur with Richards' critique of (some types of) feminism as a "rigid doctrine," noting the disunity that arises from theoretical disagreements among schools of feminist thought. Currie and Kazi deplore the rejection by some feminists of Marxist feminism, a move which the authors blame for the overall de-radicalization of the movement. ${ }^{12}$ The bulk of their essay criticizes the feminist research methodology offered by Liz Stanley and Sue Wise in Breaking Out: Feminist Consciousness and Feminist Research (1983), which identifies the conceptual split between objectivity/subjectivity as the source of gender oppression. Currie and Kazi argue that this is a misidentification, that the conceptual split itself is a product of the material conditions of society, which in turn needs to be challenged in a more systematic way. For this, (Marxist) theory is indispensable. They conclude:

Whatever the fate of the academy ... the struggle for equality must be guided by systematic theory and research. For us as academic feminists, we therefore see our struggle as both within and against the institution. ... If we are to challenge the hierarchies that occur in the academia, we require theories that help us conceptualize the processes of separation and domination that occur in that world. We see potential for such a theory grounded in dialectical historical materialism. ${ }^{13}$

By contrast, Joaquin equates Marxism with academic ideology, likening feminism to it. He claims that some people refuse the label "feminist" because of its association with "ideology:"

It is somewhat depressing to think that feminism as a socio-political movement, which promotes equality of men and women, advocates the rights and liberties of women, and criticizes the oppression caused by the idea of gender hierarchies, would be tainted by a stigma as bad as Marx's, Stalin's, or Lenin's. ${ }^{14}$

Meanwhile, Currie and Kazi point to dialectical materialism as a theory that feminism needs in order to challenge oppressive hierarchies, whether inside or outside the academy. Their adoption of the phrase

\footnotetext{
${ }^{12}$ Ibid., 79.

${ }^{13}$ Ibid., 90.

${ }^{14}$ Joaquin, "Feminism without Philosophy," 297.
}

(c) 2017 Noelle Leslie G. dela Cruz http://www.kritike.org/journal/issue 20/dela cruz june2017.pdf 


\section{A REPLY TO JOAQUIN}

"academic ideology," as used by Richards, does not pertain to Marxism, but to feminism that rejects Marxism. Regardless of the merits of their view, I must question Joaquin's reading of the original meaning and context of "academic feminism" in Currie and Kazi's article. The strange theory-practice dichotomy - challenged as early as the ancient times by Aristotle-inheres in Joaquin's argument, but certainly not in his source text, as we have seen. It cannot be disputed that this is indeed his primary source, given his copious references to the ideas of Currie and Kazi, as well as the works cited by these authors. ${ }^{15}$ It should be noted that these writings date from the 1980s, and all of them have been taken out of context by Joaquin.

To be fair, the fraught relationship between theory and practice, or academia and politics, is a perennial subject in feminist writings. Recent work, however, points to a consensus about their inseparability, rather than their mutual exclusivity. For instance, Ahmed considers feminism to be the most efficacious model for social change, precisely because of its theoretical displacement of both the self-identified humanist subject and of the unstable and indeterminate postmodern one. ${ }^{16}$ Meanwhile, Boehm characterizes the history of the feminist movement as the history of theoretical conflict between equality and difference, concluding that engaged feminists should be more self-conscious about their own conceptual stances. ${ }^{17}$ Jenkins discusses the implications of women's underrepresentation at elite educational institutions and in high-ranking journals, concluding that feminists would do well to study the inner workings and dynamics of the academe itself as a site of sexism. ${ }^{18}$ Finally, Filipino feminist Illo reflects on her own surprised reaction to the equation of the academe with "de-politicisation," noting "how close the links were between the history of feminism in the academe-particularly in the form of Women's Studies - and the women's movement." ${ }^{19}$ It seems that, in the Philippine context, feminist de-radicalization via the academe has never been a remote threat.

15 These include Janet Radcliffe Richards, The Sceptical Feminist: A Philosophical Enquiry (London: Routledge \& Kegan Paul, 1980); Liz Stanley and Sue Wise, Breaking Out: Feminist Consciousness and Feminist Research (London: Routledge \& Kegan Paul, 1983); Gloria Bowles and Duelli Klein, eds., Theories of Women's Studies (London: Routledge \& Kegan Paul, 1983).

${ }^{16}$ Sara Ahmed, "Beyond Humanism and Postmodernism: Theorizing a Feminist Practice," in Hypatia, 11:2 (1996): 71-93.

${ }^{17}$ Beth A. Boehm, “Feminist Histories: Theory Meets Practice," in Hypatia, 7:2 (1992): 202-214.

${ }^{18}$ Fiona Jenkins, "Epistemic Credibility and Women in Philosophy," in Australian Feminist Studies, 29:80 (2014): 161-170.

19 Jeanne Frances I. Illo, "'Politics' and Academic Feminist Theorising: Reflections on Women's Studies in Asia," in Australian Feminist Studies, 20:47 (2005): 195-205.

(c) 2017 Noelle Leslie G. dela Cruz

http://www.kritike.org/journal/issue 20/dela cruz june2017.pdf

ISSN 1908-7330

(cc) BY-NC-ND 


\section{Examples of Feminist Philosophical Work in the Service of Social Change}

Finally, in this last part of my essay, I would like to cite some recent feminist works that further debunk the specious separation between theory and practice, between intellectualization or conceptualization and political advocacy:

1. Daly examines the vagueness associated with ordinary notions of sex, based on the 2012 International Olympic Committee's eligibility stipulations for women. Daly argues that, for moral and practical reasons, the vagueness of concepts such as sex is better described through semantic rather than epistemic approaches. ${ }^{20}$

2. Doan develops a critical-feminist analysis of the phenomenon of complacency in regard to climate change, arguing that existing philosophical accounts of complacency are inadequate in addressing the problem. His analysis enumerates a set of "motivational vices" that need to be recognized. ${ }^{21}$

3. Shildrick applies feminist Donna Haraway's cyborg theory to Critical Disability Studies, presenting a non-binary view of the lived experience of people with prostheses. ${ }^{22}$

4. Weir takes on the issue of agency in relation to the practices of women in the mosque movement in Cairo, Egypt, arguing that these practices point to an alternative conception of freedom as one of belonging or connection. ${ }^{23}$

5. Walker and Rogers observe that surgery in contemporary health care lacks a strong evidence base. Their paper discusses the disjunct between evidence-based medicinal methods and current surgical practice, using feminist epistemology to suggest solutions. ${ }^{24}$

\footnotetext{
${ }^{20}$ Helen L. Dalay, “Sex, Vagueness, and the Olympics,” in Hypatia, 30:4 (2015): 708724.

${ }^{21}$ Michael D. Doan, "Climate Change and Complacency," in Hypatia, 29:3 (2014): 634-650.

${ }^{22}$ Margrit Shildrick, “'Why Should Our Bodies End at the Skin?': Embodiment, Boundaries, and Somatechnics," in Hypatia 30:1 (2015): 13-29.

${ }^{23}$ Allison Weir, "Feminism and the Islamic Revival: Freedom as a Practice of Belonging," in Hypatia, 28:2 (2013): 323-340.

${ }^{24}$ Mary Jean Walker and Wendy Rogers, “What Can Feminist Epistemology Do for Surgery?" in Hypatia, 29:2 (2014): 404-421.
} 


\section{A REPLY TO JOAQUIN}

6. Parkins lays down the foundations of a feminist theory of fashion, which does not treat fashion as a theoretical object but as a symptom of the widespread patriarchal disciplining of women's bodies. ${ }^{25}$

7. Ferreday analyzes the discourse of rape culture through viewers' reactions to an episode of the popular HBO television series Game of Thrones, in which the character of Jamie Lannister rapes his sister Cersei. She concludes that fan communities not only reproduce gendered narratives but also allow for the articulation of heretofore silenced trauma experiences. ${ }^{26}$

In conclusion, concerning Joaquin's central question, “Would feminism achieve its main socio-political concerns by giving philosophical foundations for them?", the above studies would seem to indicate that the answer is "Yes." Social struggles do need theory. At the very least, their goals will be more challenging and difficult to achieve without the thoughtful and scholarly work of philosophers. Philosophy-inevitably practiced now in the professionalized institution of the academe, with the attendant conferences, journal publication, and classroom discussions - provides feminists with the conceptual space to present, critique, justify, refine, and extend their political advocacies.

For a non-feminist to insist that feminists do not need philosophy is to adopt a patronizing stance that one knows what is good for a marginalized group. It is to echo the sexist, racist, heterosexist, and classist view that philosophy should be the exclusive domain of the privileged, who have never had to struggle for anything. Lastly, it is to refuse to engage with the Other, inasmuch as rational argumentation - the sort of engagement most popularly associated with philosophers - involves the most charitable interpretation of the opposing position, borne of a careful and thorough reading of it. Unfortunately, none of these philosophical courtesies seem to obtain in Joaquin's so-called polemic against "academic feminism." Thus, I offer this response essay as a correction and challenge to such a pernicious view.

Philosophy Department, De La Salle University, Philippines

${ }^{25}$ Ilya Parkins, "Building a Feminist Theory of Fashion: Karen Barad's Agential Realism," in Australian Feminist Studies, $23: 58$ (2008): 501-515.

${ }^{26}$ Debra Ferreday, "Game of Thrones, Rape Culture and Feminist Fandom," in Australian Feminist Studies, 30:83 (2015): 21-36.

(c) 2017 Noelle Leslie G. dela Cruz

http://www.kritike.org/journal/issue 20/dela cruz june2017.pdf

ISSN 1908-7330

(c) $\mathrm{BY}-\mathrm{NC}-\mathrm{ND}$ 


\section{References}

Ahmed, Sara, "Beyond Humanism and Postmodernism: Theorizing a Feminist Practice," in Hypatia, 11:2 (1996).

Boehm, Beth A., "Feminist Histories: Theory Meets Practice," in Hypatia, 7:2 (1992).

Currie, Dawn and Hamida Kazi, "Academic Feminism and the Process of DeRadicalization: Re-Examining the Issues," in Feminist Review, 25 (1987).

Dalay, Helen L., "Sex, Vagueness, and the Olympics," in Hypatia, 30:4 (2015).

Doan, Michael D., "Climate Change and Complacency," in Hypatia, 29:3 (2014).

Ferreday, Debra, "Game of Thrones, Rape Culture and Feminist Fandom," in Australian Feminist Studies, 30:83 (2015).

Illo, Jean Frances I., "'Politics' and Academic Feminist Theorising: Reflections on Women's Studies in Asia," in Australian Feminist Studies, 20:47 (2005).

Jenkins, Fiona, "Epistemic Credibility and Women in Philosophy," in Australian Feminist Studies, 29:80 (2014).

Joaquin, Jeremiah Joven, "Feminism without Philosophy: A Polemic," in Kritike, 10:2 (2016).

Parkins, Ilya, "Building a Feminist Theory of Fashion: Karen Barad's Agential Realism," in Australian Feminist Studies, 23:58 (2008).

Shildrick, Margrit, “'Why Should Our Bodies End at the Skin?': Embodiment, Boundaries, and Somatechnics," in Hypatia 30:1 (2015).

Walker, Mary Jean and Wendy Rogers, "What Can Feminist Epistemology Do for Surgery?" in Hypatia, 29:2 (2014).

Weir, Allison, Feminism and the Islamic Revival: Freedom as a Practice of Belonging," in Hypatia, 28:2 (2013). 